Ethos: Jurnal Penelitian dan Pengabdian Masyarakat, Vol 9, No.1, Januari 2021: 107-111

\title{
Penyuluhan Pemanfattan Air Nira Pohon Kelapa Menjadi Gula Semut untuk Meningkatkan Perkonomian Desa Kuripan Kabupaten Cilacap
}

\author{
${ }^{1}$ Reza Rahmadi Hasibuan, ${ }^{2}$ R. Satria Setyanugraha, ${ }^{3}$ Shella Rizqi Amelia, \\ ${ }^{4}$ Anastasia Anggarkusuma Arofah, ${ }^{5}$ Agustin Riyan Pratiwi
}

\author{
1,2,3,4,5 Universitas Perwira Purbalingga, Jawa Tengah, Indonesia \\ email: 'rezarahmadi@unperba.ac.id; ${ }^{2}$ satriasetya@unperba.ac.id, ${ }^{3}$ shellarizqi@unperba.ac.id; ${ }^{4}$ \\ anastasia@unperba.ac.id, ${ }^{5}$ agustinriyan@unperba.ac.id,
}

\begin{abstract}
Most of the residents of Kuripan Village, Kesugihan District, Cilacap Regency, work as coconut sugar processors. This work has been practiced for several years, but some residents are still not well off. It can be seen that the results of coconut sugar processing have good development prospects and a lot of high consumer demand in the market. This situation is caused by fluctuating sugar prices and the weak price position of sugar farmers. Several groups around Cilacap Regency have started to develop an ant sugar business. Ant sugar business has good prospects for development, this is due to its higher market price and is in great demand compared to sugar cubes. The conversion of block sugar to ant sugar is a product development that can be developed in order to solve the problem of coconut sugar craftsmen and with support for effective marketing methods. The counseling was followed by the practice of making sugar ants. The next stage is an effective marketing method so that the marketing process can be maximized and provide benefits to sugar farmers.
\end{abstract}

Keywords: Kuripan Village, Ant sugar

\begin{abstract}
Abstrak. Penduduk Desa Kuripan Kecamatan Kesugihan Kabupaten Cilacap kebanyakan dari penduduk bekerja manjadi pengolah gula kelapa. Pekerjaan tersebut sudah ditekuni beberapa tahun, tetapi beberapa penduduk masih belum sejahtera. Dapat diketahui bahwa hasil olaha gula kelapa memiliki pengembangan prospek yang baik dan banyak perminat dari konsumen yang tinggi di pasar. Keadaan seperti ini disebabkan harga gula yang naik turun dan lemahnya posisi harga dari petani gula. Pembuatan usaha gula semut sudah mulai digelutioleh beberapa kelompok di sekitar Kabupaten Cilacap. Usaha gula semut memiliki pengembangan prospek yang baik, hal ini dikarenakan dari sisi harga dipasar yang lebih tinggi dan banyak diminati dibandingkan gula balok. Beralihnya gula balok menjadi gula semut merupakan pengembangan produk yang dapat dikembangkan agar dapat menyelesaikan masalah pengrajin gula kelapa dan dengan adanya dukungan pada metode pemasaran yang efektif. Penyuluhan diikuti dengan praktek pembuatan gula semut. Tahapan berikutnya adalah cara pemasaran yang efektif agar proses pemasaran dapat maksimal dan memberikan keuntungan kepada para petani gula.
\end{abstract}

Kata Kunci: Desa Kuripan, Gula semut

\section{Pendahuluan}

Gula kelapa merupakan produk olahan nira kelapa dari komoditas pertanian dan perkebunan yang memiliki prospek yang bagus dari mancanega. Pengembangan yang baik pada gula kelapa tidak diimbangi dengan cerahnya kehidupan pengrajin. Kondisi ini disebabkan oleh harga gula berfluktuasi dan ditunjang pada posisi tawar pengrajin yang lemah (Arista, 2011). Hal ini juga terjadi pada masyarakat desa kuripan kecamatan 
kesugihan, kabupaten Cilacap. Masyarakat di kedua desa ini sebagian besar berprofesi sebagai pengrajin gula kelapa. Pekerjaan tersebut sudah ditekuni bertahun-tahun secara turun temurun, namun sebagian besar warganya masih belum menikmati kesejahteraan dari pekerjaanya sebagai pengrajin gula merah.

Kecamatan Kesugihan, Desa kuripan Kabupaten Cilacap memiliki luas wilayah $8.230,62 \mathrm{Ha} / 82,31 \mathrm{Km} 2$ dengan batas wilayah:

1. Utara : Kabupaten Banyumas

2. Timur : Kecamatan Maos, dan Kecamatan Adipala Kabupaten Cilacap

3. Selatan: Samudera Hindia

4. Barat : Kecamatan Cilacap Utara, Kabupaten Cilacap

Gula kelapa merupakan hasil pengolahan nira kelapa dengan cita rasa yang khas sehingga penggunaannya tidak dapat digantikan oleh jenis gula yang lain. Selain berfungsi sebagai pemanis, gula kelapa juga berfungsi sebagai pemberi warna coklat. Produk gula kelapa yang terdapat di market pada pengrajin masih terdapat kekurangan seperti hanya bertahan antara dua sampai empat minggu pada suhu ruangan, tidak tersedianya pengemasan yang baik, serta kurang praktis dalam penyajian. Oleh karena hal tersebut, peralihan perubahan bentuk gula kelapa dari balok menjadi kristal (gula semut) merupakan salah satu alternatif produk yang dapat membuat gula kelapa memiliki umur simpan yang lebih panjang serta memiliki kemudahan dalam penyajian.

Gula semut adalah gula kelapa dalam bentuk bubuk yang dapat dibuat dari air nira (tuak) palma, yaitu suatu larutan gula cetak palmae yang telah dilebur kembali dengan penambahan air pada konsentrasi tertentu. Kualitas gula semut pada kualitas yang baik diperoleh dari air nira kelapa yang baik (Irawan dan Arief, 2019). Bentuk gula semut yang serbuk menyebabkan gula mudah larut dan praktis dalam penyajian, dapat dikemas dengan rapi dan mudah dibawa dan dapat di simpan yang lama kelapa memiliki kadar air yang rendah. Selain memiliki kelebihan, kelemahan dari gula semut adalah pada proses pengadukan yang dimulai dari awal pemasakan hingga pendinginan sehingga harga gula semut lebih tinggi dari pada gula kelapa (Euis, 2019).

Masalah utama yang ditemui dilapangan adalah dalam proses pengolahan dan bagaimana proses pemasaran yang baik sehingga dapat meningkatkan perekonomian masyarakat didesa tersebut (Purwanti, 2012). Hal ini dikkelapaakan akses jalan yang masih berbatuan, pusat kecamatan dengan desa membutuhkan waktu cukup lama. Sehingga untuk mengubah paradigma masyarakat, kami ingin memberikan penyuluhan proses pembuatan gula kelapa menjadi gula semut dan bagaimana proses pemasaran yang efektif agar dapat dilaksanakan. Permasalahan yang mengganjal masyarakat adalah keterbatasan ilmu pengetahuan oleh petani dalam upaya proses pengolahan air nira kelapa menjadi gula semut dan bagaimana proses pemasaran yang baik.

\section{Metode Penelitian}

Model Pemberdayaan dalam mentransfer ilmu dan teknologi atau cara pengolahan air nira kelapa menjadi gula semut menggunakan metode pendampingan praktek langsung di lapangan mulai dari proses penyadapan, pemasakan hingga pencetakan gula semut serta bagaimana proses pemasaran yang efektif.

Bentuk program yang telah dilaksanakan pada pengabdian adalah program pengolahan air nira kelapa menjadi gula semut. Pelaksanaan pengolahan air nira kelapa menjadi gula 
semut yang rencananya meliputi penyuluhan atau pelatihan pengolahan air nira kelapa menjadi gula semut dan bagaimana proses pemasaran yang efektif.

Tabel 1. Program Kegiatan

\begin{tabular}{|c|c|c|c|}
\hline $\begin{array}{c}\mathrm{N} \\
\mathrm{O}\end{array}$ & Program & $\begin{array}{c}\text { Indikator } \\
\text { keberhasi } \\
\text { lan yang } \\
\text { dicapai }\end{array}$ & $\begin{array}{c}\text { Catatan } \\
\text { perkemban } \\
\text { gan } \\
\text { kegiatan }\end{array}$ \\
\hline 1 & $\begin{array}{l}\text { Penyulu } \\
\text { han } \\
\text { pembuat } \\
\text { an gula } \\
\text { semut } \\
\text { (diawali } \\
\text { dari } \\
\text { proses } \\
\text { pemasak } \\
\text { an air } \\
\text { nira } \\
\text { hingga } \\
\text { menjadi } \\
\text { semut } \\
\text { serta } \\
\text { proses } \\
\text { pemasar } \\
\text { an yang } \\
\text { efektif }\end{array}$ & $\begin{array}{l}\text { Kelompo } \\
\mathrm{k} \\
\text { masyarak } \\
\text { at dapat } \\
\text { mengetah } \\
\text { ui proses } \\
\text { pembuata } \\
\mathrm{n} \text { gula } \\
\text { semut } \\
\text { serta } \\
\text { memaha } \\
\text { mi } \\
\text { bagaiman } \\
\text { a proses } \\
\text { pemasara } \\
\mathrm{n} \text { yang } \\
\text { baik }\end{array}$ & $\begin{array}{l}\text { Adanya } \\
\text { keterampil } \\
\text { an dalam } \\
\text { proses } \\
\text { pengolaha } \\
\text { n gula } \\
\text { semut }\end{array}$ \\
\hline
\end{tabular}

\section{Hasil dan Pembahasan}

Kelapa adalah komoditas tanaman kehutanan. yang populasinya banyak tersebar di Indonesia. Desa kuripan merupakan salah satu desa yang terletak di kecamatan kesugihan Kabupaten Cilacap. Di desa kesugihan ini banyak terdapat pohon kelapa yang tumbuh. Sebagian masyarakat desa ini telah lama memanfaatkan nira kelapa baik sebagai bahan baku dalam pembuatan gula kelapa ataupun dijadikan tuak/saguer.

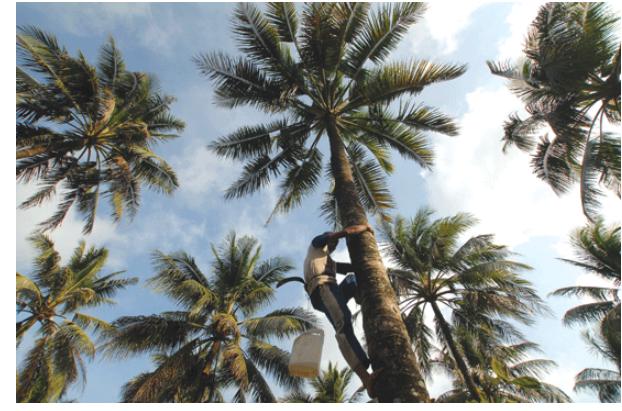

Gambar 1. Pengambilan nira kelapa Kegiatan penyuluhan bagi kelompok usaha gula merah ini dilakukan di desa kuripan kecamatan kesugihan pada bulan Januari 2020. Rangkaian kegiatan dimulai dengan rapat koordinasi team pelaksana yang akan memberikan penyuluhan tentang seluk beluk gula semut, kemudian melakukan dilanjutkan rapat koordinasi bersama dengan kelompok untuk menetapkan waktu kegiatan yang akan dilaksanakan, urutan kegiatan yang akan direalisasikan dengan kelompok, persiapan bahan baku yang akan digunakan oleh tim dan kelompok pada saat kegiatan berlangsung. Penyuluhan perdana awal diinformasikan kepada kelompok agar mengetahui potensi dari gula kelapa menjadi gula semut besarta proses pengolahannya, dan bagaimana proses pemasaran yang efektif.

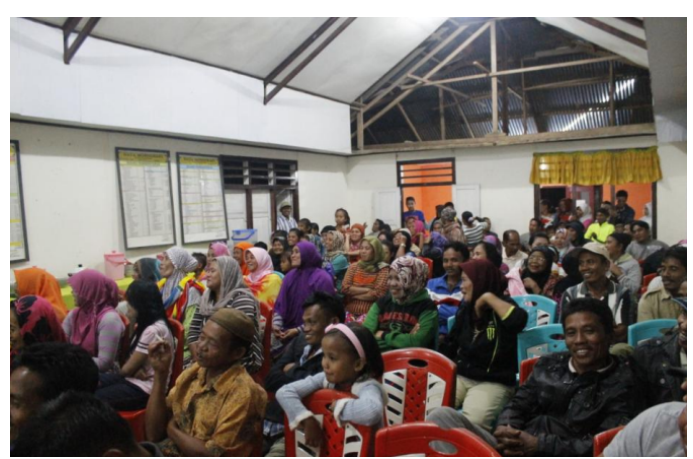

Gambar 2. Penyuluhan kepada masyarakat

Kelompok mendapat tugas untuk menyiapkan tempat dan waktu penyuluhan, dalam pembuatan nira menjadi gula semut. Team menyiapkan bahan materi yang akan disampaikan kepada kelompok dan masyarakat 
bagaimana cara pembuatan gula semut dan pemasaran yang efektif.

Hal yang pertama kali sulit dan kendala yang dihadapi oleh kelompok dan team pelaksana adalah, pada saat penyuluhan, masyarakat cenderung belum memahami potensi pada nira kelapa yang bisa dijadikan gula semut sehingg dapat menaikkan harga jual ataupun meningkatkan perekonomian masyarakat. Hal ini dikarenakan pada saat penyuluhan, team menjelaskan bagaimana proses pembuatan gula semut yang berawal dari nira kelapa, yang membutuhkan waktu minimal pemasakan nira selama 4 (empat) jam dengan mempertahankan pengapian dan selalu diaduk, setelah mulai mengental kemudian di dinginkan namun dengan mengaduk yang membutuhkan waktu kurang lebih 1 (satu) jam, sampai menjadi gula semut, setelah menjadi gula semut masuk pada proses pengeringan dengan menjemur gula semut selama 1 hari penuh dengan catatan terkena sinar matahari, jika tidak ada matahari, membutuhkan proses pengeringan hingga beberapa hari. Hal ini yang menyebabkan team pelaksana mengalami kendala dalam mengubah persepsi masyarakan desa agar bisa beralih yang tadinya hanya membuat gula balok menjadi gula semut. Pada akhirnya masyarakat bisa mulai memahami penyuluhan tersebut untuk bisa meningkatkan produktivitas dan perekonomian masyarakat desa.

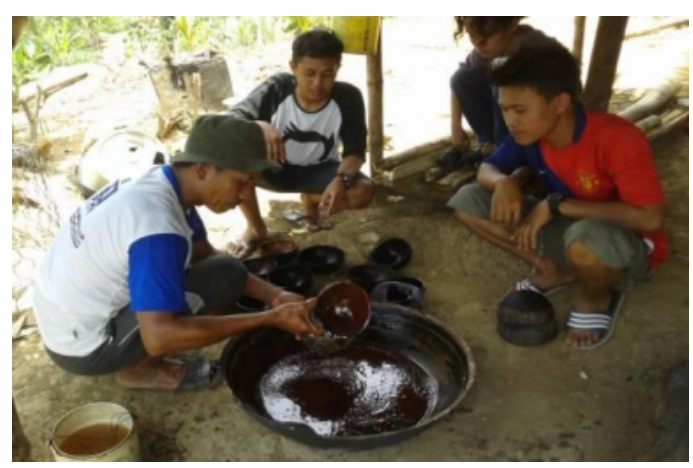

Gambar 3. Proses pembuatan gula balok

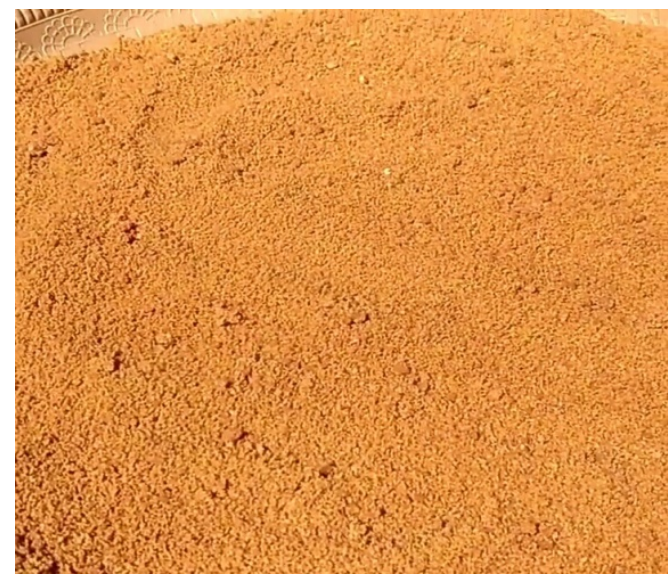

Gambar 4. Gula semut kelapa

Penyuluhan bagaimana cara pemasaran yang efektif dijelaskan oleh team, team menjelaskan bagaimana pemasaran yang efektif saat ini menggunakan jejaring sosiang atau internet. Namun, kendala yang dihadapi di desa tersebut, masyarakat sekitar belum memahami perihal tersebut, yang selama ini dilakukan adalah, masyarakat membuat gula, kemudian langsung diperjual belikan di pasar. Kami memberikan penyuluhan pemasaran yang efektif saat ini sudah menggunakan social media. Kendala tersebut dapat diatasi dengan team memberikan arahan kepada remajaremaja disana untuk dapat membantu bagaimana cara jual beli menggunakan social media.

\section{Kesimpulan dan Saran}

Terselesaikannya kegiatan penyuluhan yang diberikan oleh kelompok masyarakat menghasilkan kesimpulan bahwa dengan dilakukannya penyuluhan ini, kelompok dapat mengetahui potensi hasil proses dari air nira menjadi gula semut, memiliki keterampilan mengolah air nira menjadi gula semut. Hasil dari penyuluhan ini diharapkan dapat menjadi ilmu yang bermanfaat pada 
kelompok dan dapat menaikkan perekonomian masyarakat tersebut. Hasil penyuluhan ini juga diharapkan menjadi contoh untuk kelompok desa yang lain agar dapat mengolah air nira menjadi gula semut.

Tim memberikan arahan agar membentuk koperasi didesa untuk memperoleh pendanaan maupun sebagai penyalur gula semut dari petani kepada penjual dan proses pemasaran yang dapat membantu petani dalam memasarkan produk gula semut.

\section{DAFTAR PUSTAKA}

Arista, D., \& Astuti, S. R. T. (2011). Analisis pengaruh iklan, kepercayaan merek, dan citra merek terhadap minat beli konsumen. Jurnal Aset, 13(1), 37-45. http://kesugihan.cilacapkab.go.i $\mathrm{d} /$ profil/monografi/. Diakses pada tanggal 15 Januari 2020.

BPS. 2019. Kecamatan Kesugihan dalam Angka. Cilacap 2019
Euis F.S. Pangemanan, Wawan Nurmawan dan Marthen T. Lasut, 2019. Pembuatan Gula Semut Dari Aren Di Kelurahan Kayawu, Tomohon, Sulawesi Utara. Pros Sem nas Masy Biodiv Indon, Vol 5 No. 2 juni 2019. ISSN : 2407-8050, DOI : $10.13057 / \mathrm{psnmbi} / \mathrm{m} 050223$. 276-279

Irawan Wisnu Wardhana dan M. Arief Budihardjo, 2019. Pembuatan Gula Semut Kelapa Jahe Di Desa UjungUjung, Kec. Pabelan, Kab. Semarang. Jurnal Pasopati, Vol 1, No. 2, Tahun 219, 51-55

Purwanti, E. (2012). Pengaruh karakteristik wirausaha, modal usaha, strategi pemasaran terhadap perkembangan UMKM di Desa Dayaan dan Kalilondo Salatiga. Jurnal Ilmiah Among Makarti, 5(9), $13-28$. 